\title{
Content and composition of dissolved organic carbon in precipitation at the southern part of Mexico City
}

\author{
Guillermo MONTERO-MARTÍNEZ ${ }^{1 *}$, Joel RIVERA-ARELLANO ${ }^{1}$, Priyadarsi D. ROY ${ }^{2}$, \\ Anielka ROSADO-ABÓN ${ }^{3}$, Déborah Patricia HERNÁNDEZ-NAGAY ${ }^{1}$, Angélica MENDOZA-TREJO ${ }^{1}$ \\ and Gema Luz ANDRACA-AYALA ${ }^{1}$
}

${ }^{1}$ Centro de Ciencias de la Atmósfera, Universidad Nacional Autónoma de México, Circuito de la Investigación Científica s/n, Ciudada Universitaria, 04510 Ciudad de México, México.

${ }^{2}$ Instituto de Geología, Universidad Nacional Autónoma de México, Circuito de la Investigación Científica s/n, Ciudada Universitaria, 04510 Ciudad de México, México.

${ }^{3}$ Instituto de Química, Universidad Nacional Autónoma de México, Circuito de la Investigación Científica s/n, Ciudada Universitaria, 04510 Ciudad de México, México.

*Corresponding author; email: gmontero@atmosfera.unam.mx

Received: August 28, 2017; accepted: June 15, 2018

\section{RESUMEN}

Se presentan las concentraciones de carbono total disuelto (TC) y carbono orgánico (OC) en muestras de agua de lluvia recolectadas durante 2016 en el sur de la Ciudad de México. El TC varió de 10 a $25 \mathrm{mgC} \mathrm{L}^{-1}$ y el OC, reportado como carbón orgánico no purgable (NPOC, por sus siglas en inglés), tuvo un rango de 2.5 a $20 \mathrm{mgC} \mathrm{L}^{-1}$. Los valores más altos de NPOC se midieron en las muestras recolectadas entre mayo y julio, y se detectó un cambio en la razón de NPOC/TC para la segunda parte de la campaña (es decir, agosto-octubre). El análisis por ${ }^{1} \mathrm{H}$ RMN sugiere que aldehídos, ácidos carboxílicos y otros hidrocarburos oxigenados constituyen la fracción orgánica disuelta en las muestras de precipitación. La evaluación de las trayectorias de las masas de aire no encontró ninguna relación entre los contenidos de compuestos orgánicos y las direcciones del viento dominante para la formación de las tormentas, lo que sugiere que los compuestos orgánicos disueltos en el agua de lluvia tienen su origen en fuentes dentro de la cuenca de México. Además, los valores de pH más altos en las muestras estudiadas indican que la neutralización de la lluvia ocurre cuando las tormentas provienen del norte de la ciudad, donde se encuentran las fuentes de los agentes que producen este efecto.

\begin{abstract}
We present concentrations of dissolved total carbon (TC) and organic carbon (OC) in rainwater samples collected in 2016 in the southern part of Mexico City in a preliminary study. TC ranged from 10 to $25 \mathrm{mgC} \mathrm{L}^{-1}$ and $\mathrm{OC}$ - reported as non-purgable organic carbon (NPOC) - varied between 2.5 and $20 \mathrm{mgC} \mathrm{L}^{-1}$. NPOC concentrations were higher in samples collected between May and July and a change in the ratio of NPOC/TC was detected for the second part of the campaign (i.e., August-October). ${ }^{1} \mathrm{H}$ NMR analysis indicated presence of aldehydes, carboxylic and other oxygenated hydrocarbons in the precipitation. An evaluation of air mass back-trajectories suggested no relationship between the organic contents and wind directions. Carbon contents were originated from sources within the basin of Mexico and higher $\mathrm{pH}$ of rainwater during the passage of air masses indicates that the sources causing rain neutralization are located in northern parts of the city.
\end{abstract}

Keywords: Water-soluble organic compounds, rainwater characterization, rain neutralization, urban pollution, Mexico City. 


\section{Introduction}

Carbon is present as gaseous and condensed phases in the atmosphere and both of them are associated with anthropogenic and biogenic sources (Siudek et al., 2015). Atmospheric aerosols contain inorganic (IC) and organic carbon (OC). More than $2300 \mathrm{Tg}$ of OC are emitted annually into the atmosphere and a significant fraction remains in the condensed aerosol phase (Yan and Kim, 2012; Nozière et al., 2015), affecting air quality and the radiative balance of the atmosphere (Gilardoni et al., 2016), both in urban and rural locations (Putaud et al., 2004; Zhang et al., 2007). The organic fraction includes saturated and unsaturated aliphatic compounds, aromatics, alcohols, ketones, aldehydes, carboxylic acids, amines, sugars, polyols, and organic sulphur compounds (Seinfeld and Pandis, 2006). OC is ubiquitous in urban locations (e.g., Zhang et al., 2007) and constitutes a major component (20-90\% of the total mass) of the sub-micron atmospheric aerosol particles (Kanakidou et al., 2005; Moffet et al., 2010). Furthermore, it has been shown that water-soluble organic compounds (WSOC) represent $20-70 \%$ of the total organic aerosol mass (Saxena and Hildemann, 1996; Facchini et al., 1999) and can reach a considerable fraction $(\sim 50 \%)$ of the total water-soluble materials in the size range of the cloud condensation nuclei (Huang et al., 2006).

Wet deposition processes (e.g., rainout and washout) remove particulate material and pollutants from the atmosphere (Guidotti et al., 2000; Kawamura et al., 2001; Seinfeld and Pandis, 2006; Balla et al., 2014). Therefore, OC is a typical constituent of rainwater (Balla et al., 2014) and it can be used as an initial screening of air quality in different urban and/or industrial areas (Guidotti et al., 2000), and to infer some of its effects on ecosystems (Santos et al., 2009). WSOC are poorly understood due to their inherent complexity and difficulties in chemical analysis, even though they are essential components of atmospheric aerosols. The organic fraction consists of low-molecular weight (MW) polar compounds (Saxena and Hildemann, 1996; Kawamura et al., 2001) as well as high-MW, polydisperse macromolecules, termed as humic-like substances (HULIS) due to their similarities to terrestrial humic acids (Graber and Rudich, 2006). During the last two decades, OC present in the atmosphere was characterized using chromatographic techniques, mass and UV spectrometry, and nuclear magnetic resonance, among others; however, there remain many challenges in this research field (Nozière et al., 2015). Studies of OC in precipitation are scarce compared to those for other atmospheric substrates, but results indicate that $\mathrm{OC}$ in rainwater is lower compared to concentrations observed in snow and fog (Iavorivska et al., 2016 and references therein). Some of the previous reports have focused on the measurement of total WSOC concentrations (Coehlo et al., 2008; Pan et al., 2010; Yan and Kim, 2012; Siudek et al., 2015) and others have characterized the different fractions by using gas, liquid, and UV-visible chromatographies; molecular fluorescence; FTIR-ATR, and ${ }^{1} \mathrm{H}$ NMR spectroscopies (Santos et al., 2009; Xu et al., 2008; Guidotti et al., 2000; Ćosović et al., 2007; Chon et al., 2015).

Previous studies on rainwater characterization in samples from Mexico City were conducted by analyzing major inorganic ions and trace elements (Báez et al., 2006, 2007; 2009; García et al., 2006). Báez et al. $(1989,1993,2008)$ measured organic compounds in rainwater samples but focused only on carbonyl compounds. Balla et al. (2014, and references therein) reported that aldehydes constitute up to $16 \%$ of dissolved OC in rainwater samples. This study aims to measure the total organic content and characterize the organic compounds present in rainwater samples collected in an urban area of Mexico City during 2016. As rain collects air pollutants in gaseous and liquid phase, the determination and characterization of OC could be used as a screening of air quality in the area and for the study of surface-active effects (a key factor in the collision-coalescence process) in fog and cloud droplets due to the presence of these organic compounds.

\section{Experimental}

Mexico City's metropolitan area (MCMA) is located to the southwest of the basin of Mexico. Except for the northeast, this basin is surrounded by mountains, some of them with altitudes higher than 4500 masl. Due to the subtropical latitude and the mean altitude $(2250 \mathrm{~m})$ of the basin, the intense solar radiation promotes the formation of photochemical pollutants in the area (Salcedo et al., 2006). The main rainy 
season - in terms of accumulated rain - occurs from May to October (summer and autumn), and it is characterized by the development of convective clouds with warm bases and cold tops (Kucieńska et al., 2010) with predominant winds coming from north-northeast (Jáuregui, 2000). Furthermore, the passage of cold fronts during the winter produces a second rainy season, although its contribution in terms of precipitated water quantity is much lower (Montero et al., 2011).

The sampling site is located on the roof of the Centro de Ciencias de la Atmósfera (Atmospheric Sciences Center, CCA) building $\left(19.33^{\circ} \mathrm{N}, 99.18^{\circ} \mathrm{W}\right.$, 2280 masl) of the National Autonomous University of Mexico (Fig. 1), in the southwestern part of Mexico City. Instrumentation includes diverse sensors for the measurement of common meteorological parameters (temperature, pressure, wind direction and intensity, etc.) and evaluation of air quality. A Texas Electronics TR-525M tipping bucket rain gauge records rainfall intensity with a resolution of $0.1 \mathrm{~mm}$ and an accuracy of $1 \%$. Rainwater samples were gathered from May to October 2016 on an event basis. Sample collection was made with a stainless steel funnel in order to avoid problems of absorption of organic compounds

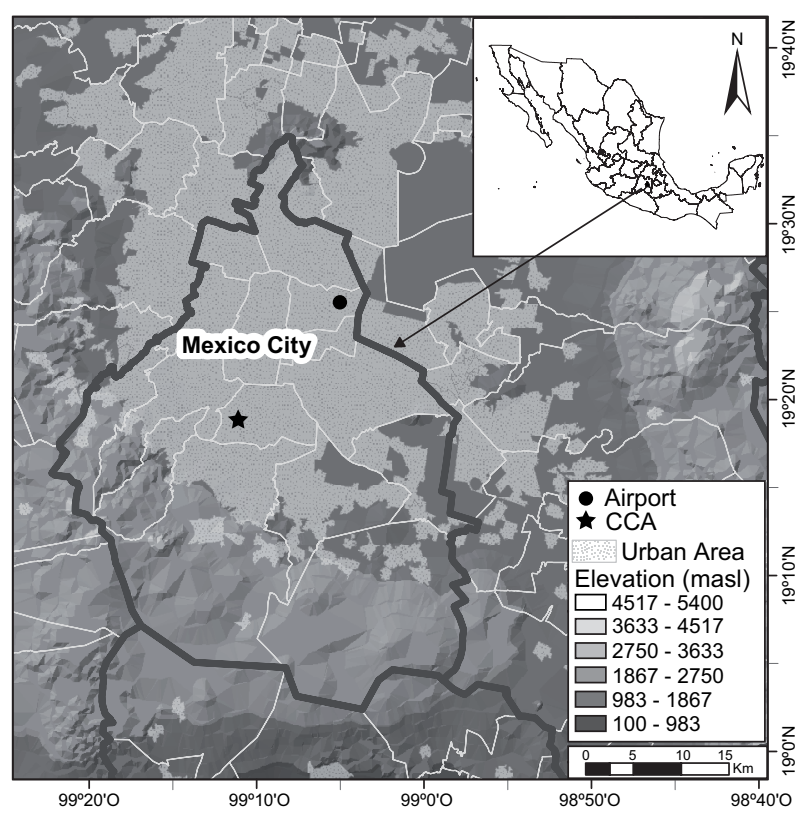

Fig. 1. Geographical location of the basin of Mexico, its main orographic features as well as the locations mentioned in the text. on the surface (Decesari et al., 2000) and amber glass bottles (washed with both deionized and grade HPLC water and combusted at $280^{\circ} \mathrm{C}$ during $24 \mathrm{~h}$ to remove volatile organic compounds). All the samples were filtered and stored in amber bottles - sealed with an aluminum foil baked at $280^{\circ} \mathrm{C}$ - and kept in refrigeration at $4{ }^{\circ} \mathrm{C}$ after collection until analyzed. Filtration was done using filters TITAN3 (manufactured by Thermo Scientific) with nylon membrane and a diameter pore of $0.45 \mathrm{~mm}$ previously washed with deionized water.

\subsection{Characterization of organic compounds}

Proton nuclear magnetic resonance $\left({ }^{1} \mathrm{H}\right.$ NMR) spectroscopic analysis was done to obtain preliminary information about the organic matter dissolved in rainwater and aerosol samples. Some important characteristics of this technique include that good results - spectra - can be acquired to identify the functional groups of organics in one sample and the small amount (about 5 to $30 \mathrm{mg}$ ) necessary to perform the assays (Suzuki et al., 2001). Rain samples were dried using a rotary evaporator with a high purity nitrogen flow at ambient temperature (ca. $20^{\circ} \mathrm{C}$ ). ${ }^{1} \mathrm{H}$ NMR spectra were recorded in deuterated water $(\sim 0.6 \mathrm{~mL})$ with an Eclipse JEOL 300 spectrometer.

\subsection{Carbon analysis}

Concentrations of total carbon (TC) and organic carbon (OC) dissolved in the rainwater samples were estimated by high temperature non-catalytic temperature using a Thermo Scientific HiperTOC carbon analyzer with an auto-sampler. The HiperTOC uses a dual NDIR approach (15.2 and $38.1 \mathrm{~cm}$ sample cells) to detect $\mathrm{CO}_{2}$ levels. Both detectors are calibrated to $1 \% \mathrm{CO}_{2}$ full scale and operate reliably in the 0-1000 ppm $\mathrm{CO}_{2}$ gas range (Thermo Scientific, 2007). All results were gathered from the detector with the longest cell (low bench detector). Total OC was measured as Non-purgeable organic carbon (NPOC), which estimates the non-volatile OC (Saarikoski et al., 2008). The procedure involves removal of inorganic carbon (IC) by treatment with acid $\left(\mathrm{Na}_{2} \mathrm{~S}_{2} \mathrm{O}_{8}\right.$, also known as persulfate) prior to measuring the $\mathrm{OC}$ (Bisutti et al., 2004). The reference solutions for OC determinations were prepared from reagent grade anhydrous potassium hydrogen phthalate (KHP), while a mixture of anhydrous sodium carbonate and 
anhydrous sodium hydrogen carbonate was used for TC measurements. To perform carbon analyses, $0.25 \mathrm{~mL}$ of solution (sample) was injected into the analyzer, which oxidizes carbon at $1000{ }^{\circ} \mathrm{C}$ without a catalyst. In particular, for NPOC measurements, the acidified samples were sparged with $\mathrm{CO}_{2}$ free carrier gas (UHP oxygen [99.8\% purity] with $<0.5 \mathrm{ppm}$ of total hydrocarbons) at a flow rate of $200 \mathrm{~mL} / \mathrm{min}$ for $5 \mathrm{~min}$ to remove inorganic carbon prior to the actual analysis. Total IC can be estimated as the difference between TC and NPOC.

\subsection{Back trajectory analysis}

Backward trajectories of the air masses were calculated based on the hybrid single-particle Lagrangian integrated trajectory model - NOAA HYSPLIT (Stein et al., 2015) - to study a potential association between air masses and the organic contents in rainwater. The input parameters were as follows: meteorological database, NARR; trajectory duration, 48-h; vertical motion based on model vertical velocity, and starting heights, 500 and $1500 \mathrm{~m}$ above the ground level. Both height levels are within the air layer below the cloud base of the storms that occur in the area during the sampling period (Montero et al., 2011). The lowest level aims to facilitate studying the differences in the air mass trajectories closest to the superficial pollution sources with respect to those at higher levels.

The Red Automática de Monitoreo Ambiental (Automated Environmental Monitoring Network, RAMA) (http://www.aire.cdmx.gob.mx) employs 29 stations distributed throughout Mexico City to provide information about the pollutant levels. The hourly air pollution data from a RAMA station installed in the sampling site (CCA) was used in this study.

\section{Results and discussion}

\subsection{Characterization of organics by ${ }^{1} H$ NMR}

Based on the results of previous reports for urban areas worldwide (a few dozens of mg of carbon per liter of rainwater) and volumes of the collected samples during the first part of this study (less than $500 \mathrm{~mL}$ ), it was decided to mix a pair of samples in order to get enough material for the ${ }^{1} \mathrm{H}$ NMR analysis. The selected samples correspond to events occurred during the first part of the rainy season. The mixture of rainwater samples was injected into the ${ }^{1} \mathrm{H}$ NMR instrument to obtain a proxy of the diversity of soluble compounds contained in the precipitation over the study area. Fig. 2 shows the gathered spectrum for the solution prepared after mixture two rainwater samples. Four or five categories of functional groups have usually been identified in aerosol and fog water samples (Decesari et al., 2000; Graham et al., 2002; Cavalli et al., 2006; Duarte and Duarte, 2011). The peak at 9.67 ppm can be attributed to aldehyde protons. Chemical shifts in the spectral region between 7.25 and 7.9 ppm suggest protons in aromatics with electron-attractor substituents such as -CHO and -COOH. On the other hand, the shifts at about 6.8 ppm may be attributed to hydroxyl- and methoxylsubstituents in the aromatic hydrocarbons. Signals between 3.59 and $4.36 \mathrm{ppm}$ correspond to aliphatic protons adjacent to alcohols and ethers. In addition, there are signals between 2.02 and 2.77 ppm corresponding to aliphatic protons adjacent to aromatic rings or carbonyl groups. Aliphatic protons adjacent to methylene groups and/or alcohols are abundant in the 1.25-1.5 ppm spectral region. Finally, the presence of methyl groups is evidenced by the 0.93 ppm signal (Decesari et al., 2000; Suzuki et al., 2001; Pretsch et al., 2009).

The results from the ${ }^{1} \mathrm{H}$ NMR spectrum show that the composition of the water-soluble organic fraction in rainwater samples is in agreement with other previously published reports about the composition of aerosols in Mexico City, with aliphatic saturated and carboxylic acids groups as major components in sub-micron particles (Gilardoni et al., 2009) and other atmospheric pollutants. This suggests that composition of the water-soluble organic fraction in rainwater over the sampling site is due to the occurrence of wet deposition processes.

Báez et al. (1989, 1993, 2008) detected carbonyl compounds, especially formaldehyde, both in rainwater and particulate samples from Mexico City and other near places. They associated the presence of these compounds with anthropogenic emissions (motor vehicles exhaust). Aromatic and aliphatic acids have also been detected in rainwater samples from urban areas around the world (Chon et al., 2015). It is known that gaseous aliphatic and aromatic anthropogenic volatile organic compounds (VOCs) can produce particulate 


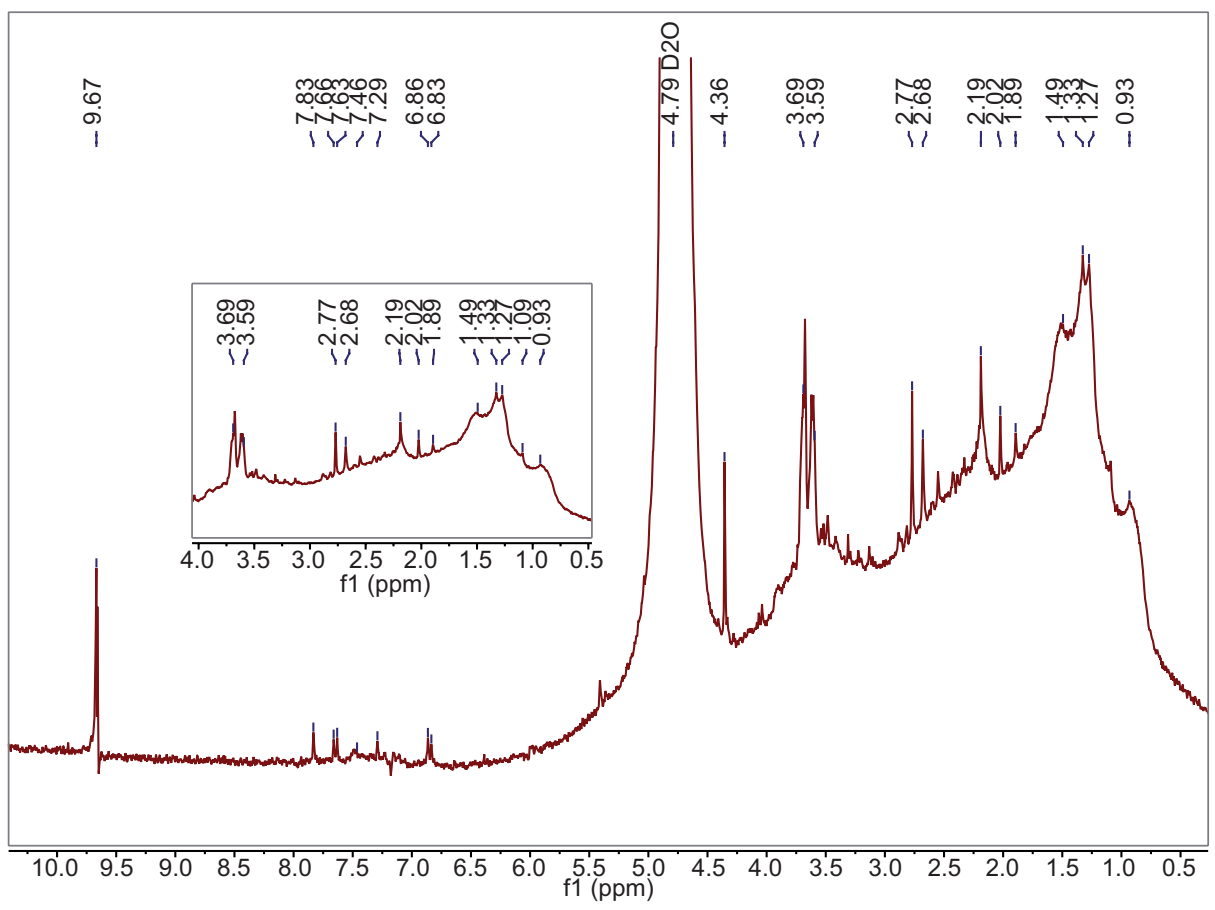

Fig. 2. ${ }^{1} \mathrm{H}$ NMR spectrum at $300 \mathrm{MHz}$ for the rainwater extract. The reported chemical shifts are referred to deuterated water used to dissolve the remnants after the extraction.

aliphatic and aromatic carboxylic acids and aldehydes via secondary organic aerosols (SOA) formation, but these organic acids and aldehydes can also be emitted directly by motor vehicles (Sullivan et al., 2006 and references therein) and cigarette emissions (Chon et al., 2015). Low molecular weight carboxylic acids mainly originate from vehicular exhaust but can also be produced by photo-oxidation of terpenes emitted from biological organisms (Sun and Ariya, 2006). Aliphatic acids have their origin from both primary natural (microbial activity and vegetation) as well as anthropogenic sources (biomass burning and traffic exhaust). Finally, the organic carbon in aerosol particles produced from biomass burning has been shown to be predominately aliphatic, composed mainly of oxygenated compounds with a minor content of aromatic compounds containing poly acidic compounds and phenols (Graham et al., 2002; Sullivan et al., 2006). This analysis and the report of Tsimpidi et al. (2011) indicate that the main sources of organic compounds in Mexico City are anthropogenic pollution (motor vehicles, including diesel and gasoline) and biomass burning.

\subsection{TC and NPOC results}

Former storage experiments at $4{ }^{\circ} \mathrm{C}$ refer that rainwater dissolved organic carbon (DOC) concentrations were stable (3\%) for a week (Willey et al., 2000). On the other hand, Campos et al. (2007) reported that DOC loss in rainwater samples may be smooth or even not significant in samples with storage periods up to 21 days under the same conditions. In this study, the maximum variability for the analysis performed of a pair of samples with four weeks storage was of 17 and $25 \%$ for TC and NPOC, respectively. In the case of a sample with up to six weeks of storage, the depletion of organics (NPOC) amount was of 38\%. Our results for loss of organics are comparable to those from Campos et al. (2007). Table I presents the contents of TC and NPOC in rainwater samples with a storage period up to three weeks at $4{ }^{\circ} \mathrm{C}$. Carbon concentrations are expressed as $(\bar{x} \pm u n c)$, where $(\bar{x})$ is the mean value of the instrument measurements and unc is the standard deviation of the mean (SDOM) - calculated by dividing the standard deviation $\left(\sigma_{x}\right)$ with squared root of the number of injections $(\sqrt{N})$ - plus the variability due to storage. For those rainwater samples with storage period up to 
Table I. TC and NPOC concentrations, $\mathrm{pH}$ and accumulated rain data for samples collected during the field campaign. Accumulated rain is expressed in $\mathrm{mm}$ while carbon contents are reported in $\mathrm{mgC} \mathrm{L}^{-1}$ (mean \pm unc). $\mathrm{N}_{1}$ and $\mathrm{N}_{2}$ correspond to the number of analysis performed by the analyzer.

\begin{tabular}{|c|c|c|c|c|c|c|}
\hline Date & $\begin{array}{l}\mathrm{R}_{\mathrm{ac}} \\
(\mathrm{mm})\end{array}$ & $\mathrm{pH}$ & $\mathrm{N}_{1}$ & $\begin{array}{c}\mathrm{TC} \\
\left(\mathrm{mgC} \mathrm{L}^{-1}\right)\end{array}$ & $\mathrm{N}_{2}$ & $\begin{array}{c}\mathrm{NPOC} \\
\left(\mathrm{mgC} \mathrm{L}^{-1}\right)\end{array}$ \\
\hline $26 / 05 / 2016$ & 2.9 & 5.3 & 3 & $24.8 \pm 4.3$ & 3 & $16.6 \pm 4.2$ \\
\hline $02 / 06 / 2016$ & 1.8 & 6.2 & 3 & $20.3 \pm 3.5$ & 3 & $15.1 \pm 4.0$ \\
\hline 07/06/2016 & 7.2 & 4.2 & 3 & $20.6 \pm 3.5$ & 3 & $11.9 \pm 0.2$ \\
\hline $14 / 06 / 2016$ & 1.6 & 6.7 & 3 & $24.0 \pm 4.2$ & 3 & $15.4 \pm 4.1$ \\
\hline 20/06/2016 & 3.3 & 5.1 & 3 & $21.5 \pm 3.7$ & 3 & $19.4 \pm 4.9$ \\
\hline 08/08/2016 & 1.4 & 5.7 & 3 & $8.9 \pm 1.6$ & 3 & $3.5 \pm 0.9$ \\
\hline $10 / 08 / 2016$ & 4.7 & 5.5 & 3 & $9.1 \pm 1.7$ & 3 & $3.5 \pm 0.9$ \\
\hline $16 / 08 / 2016$ & 16.7 & 6.2 & 2 & $13.4 \pm 2.4$ & 1 & 3.3 \\
\hline $24 / 08 / 2016$ & 23.8 & 5.2 & 3 & $13.3 \pm 2.5$ & 3 & $3.4 \pm 0.9$ \\
\hline 06/09/2016 & 2.9 & 7.3 & 3 & $11.8 \pm 1.2$ & 2 & $6.6 \pm 1.9$ \\
\hline $12 / 09 / 2016$ & 14.6 & 6.3 & 3 & $14.4 \pm 0.6$ & 3 & $3.9 \pm 0.9$ \\
\hline $13 / 09 / 2016$ & 0.4 & 6.8 & 3 & $14.9 \pm 1.5$ & 3 & $4.3 \pm 0.4$ \\
\hline 19/09/2016 & 1 & 6.7 & 3 & $15.5 \pm 2.7$ & 3 & $7.8 \pm 1.9$ \\
\hline 28/09/2016 & 6.9 & 4.4 & 3 & $11 \pm 2.2$ & 3 & $3.2 \pm 0.8$ \\
\hline $12 / 10 / 2016$ & 10.8 & 7.1 & 3 & $10.4 \pm 0.5^{\mathrm{a}}$ & 3 & $2.5 \pm 0.1$ \\
\hline
\end{tabular}

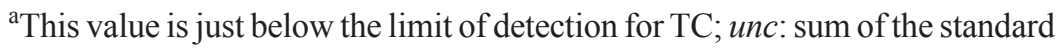
deviation of the mean plus the variability due to sample storage.

one week, unc does not include the storage variability. The limit of detection for TC and NPOC are 10.6 and $2.40 \mathrm{mgC} \mathrm{L}^{-1}$, respectively. The accumulated rain data $\left(R_{\mathrm{ac}}\right)$ correspond to the amount of precipitation event estimated by the TR-525M rain gauge.

Concentrations of TC and NPOC divide the samples into two different groups. The first one corresponds to samples collected between May and July with higher mean values of TC (22.2 mgC $\mathrm{L}^{-1}$ ) and NPOC (15.7 $\mathrm{mgC} \mathrm{L}^{-1}$ ) compared to the samples obtained for the second period between August and October (TC, $15.7 \mathrm{mgC} \mathrm{L}^{-1}$; NPOC, $\left.4.2 \mathrm{mgC} \mathrm{L}^{-1}\right)$. The difference is more evident in the case of NPOC, since concentrations are reduced significantly during the second period. A similar behavior between spring and summer is observed in Pan et al. (2010). Although the authors do not mention a clear justification for their observations during this particular period, they refer that emission changes from diverse sources during the study as well as variability in rain amounts may be responsible for the organic concentration differences. Moreover, the results for NPOC in Table I are higher than the continental rain $\left(1.9 \mathrm{mgC} \mathrm{L}^{-1}\right.$;
Willey et al., 2000), indicating that the occurrence of rain is associated with terrestrial and local features.

The relation NPOC/TC suggests that contribution of organic carbon to total carbon in rainwater fluctuated along the year. The proportion NPOC/TC was 0.7 on average during the first part of the campaign and it is comparable to the observed by Pan et al. (2010) but lower than the value reported by Siudek et al. (2015). Organic levels in our sampling site are comparable to those reported for other urban areas in China and Poland, although the larger concentrations gathered in Mexico City were not so large compared to those reported in the mentioned studies. The NPOC/ $\mathrm{TC}$ ratio in the sampling site decreases to 0.3 during the August-October period; plausible explanations regarding this difference can be that air masses were more photochemically processed during the first part of the campaign (Kondo et al., 2007) or that there was a change in the source contributions for WSOC during the sampling period (Saarikoski et al., 2008). It is worthy of note that the amount of inorganic carbon, reported as water-soluble inorganic carbon $($ WSIC $=T C$ $-N P O C$ ) in the rainwater samples for Mexico City remained similar for the whole campaign. Mexico City's 
Table II. Organic concentrations in rainwater from this study compared with other studies performed at urban areas of different parts of the world. Data show the minimum and maximum values obtained for the collected samples.

\begin{tabular}{lcl}
\hline Location & $\begin{array}{c}\text { DOC range } \\
\left(\mathrm{mgC} \mathrm{L}^{-1}\right)\end{array}$ & Reference \\
\hline Tokio, Japan & $15.4-1.2$ & Sempere and Kawamura (1994) \\
Los Angeles, USA & $18-2.0$ & Kawamura et al. (2001) \\
Guangzhou, China & $8.3-0.93$ & Xu et al. (2008) \\
Northern China & $44.1-0.3$ & Pan et al. (2010) \\
Zagreb, Croatia & $7.84-0.19$ & Orlović-Leko et al. (2010) \\
Seoul, Korea & $9.36-0.18$ & Yan and Kim (2012) \\
Thessaloniki, Greece & $21.3-0.46$ & Balla et al. (2014) \\
Poznan, Poland & $48.3-0.1$ & Siudek et al. (2015) \\
Gwangju, Korea & $6.9-0.15$ & Chon et al. (2015) \\
Mexico City & $19.5-2.4$ & This study \\
\hline
\end{tabular}

rainwater has an average of $7.6 \pm 3.5 \mathrm{mgC} \mathrm{L}^{-1}$ of WSIC, which is higher than the values reported for Poland and China and explains the larger NPOC/TC values for Poland (Siudek et al., 2015) respect to those found in our sampling site. The WSIC content found in this study is higher than the continental rain expected from Henry's Law and carbonic dissociation $\left(0.2 \mathrm{mgC} \mathrm{L}^{-1}\right.$; Willey et al., 2000) and global average (1.9 $\mathrm{mgC} \mathrm{L}^{-1}$; Liu et al., 2004), but comparable to levels reported for urban and polluted areas (up to $10 \mathrm{mgC} \mathrm{L}^{-1}$; Pan et al., 2010). It suggests that local sources contribute dominantly to this carbonaceous fraction.

A comparison of the results obtained in this study with organic concentrations measured in rainwater from several urban areas around the world is presented in Table II. Except for Los Angeles (USA), most of the studies used TOC analyzers for the measurements of carbon. Kawamura et al. (2001) oxidized the samples from Los Angeles with $\mathrm{K}_{2} \mathrm{Cr}_{2} \mathrm{O}_{4}$ and determined the resultant $\mathrm{CO}_{2}$ by a coulometric detector. Organic carbon (NPOC) content in rainwater samples from Mexico City shows a range comparable to dissolved organic concentrations reported from Tokyo (Japan), Los Angeles and Thessaloniki (Greece). However, the higher values of our study are higher compared to urban areas located at Guangzhou (southern China), Zagreb (Croatia), Seoul and Gwangju (Korea). Some of the rainwater samples from northern China and Poznań (Poland) exhibited much higher DOC concentrations (above 44 and $48 \mathrm{mg} \mathrm{L}^{-1}$, respectively) than in Mexico City.
Table III shows maximum concentrations of tropospheric $\mathrm{O}_{3}$ in the atmosphere for the sampling period of this study. It also has the average concentration of $\mathrm{PM}_{2.5}$ three hours before the rain event (i.e., $\mathrm{PM}_{2.5}$ [- $^{-}$ 3h]) - calculated from the measurements registered by the RAMA station installed at Atmospheric Sciences Center (CCA) - and the scavenging efficiencies

Table III. Maximum concentrations of $\mathrm{O}_{3}(\mathrm{ppb})$ in the atmosphere, as well as 3-h mean levels of $\mathrm{PM}_{2.5}$ registered by the CCA station (source, RAMA website) before precipitation in the sampling site. Scavenging efficiencies estimates for particulate matter and ozone are also shown.

\begin{tabular}{|c|c|c|c|c|}
\hline Date & $\begin{array}{c}\mathrm{O}_{3} \\
(\mathrm{ppb})\end{array}$ & $\begin{array}{c}\mathrm{PM}_{2.5}(-3 \mathrm{~h}) \\
\mu \mathrm{g} \mathrm{m}^{-3}\end{array}$ & $\begin{array}{c}\eta_{\mathrm{PM}_{2.5}} \\
(\%)\end{array}$ & $\begin{array}{l}\eta_{\mathrm{O}_{3}} \\
(\%) \\
\end{array}$ \\
\hline $26 / 05 / 2016$ & 123 & 31.3 & 56.7 & 40.4 \\
\hline $02 / 06 / 2016$ & 104 & 24.7 & 64.7 & 29.4 \\
\hline 07/06/2016 & 140 & 44.7 & 43.5 & 43.6 \\
\hline $14 / 06 / 2016$ & 98 & 13.7 & 26.7 & 9.7 \\
\hline $20 / 06 / 2016$ & 47 & 24.3 & 46.2 & 36.8 \\
\hline 08/08/2016 & 55 & 7.3 & 25.0 & 39.2 \\
\hline $10 / 08 / 2016$ & 81 & 15.0 & 27.8 & 55.6 \\
\hline $16 / 08 / 2016$ & 62 & 12.0 & 42.9 & 38.2 \\
\hline $24 / 08 / 2016$ & 93 & 21.3 & 28.6 & 63.9 \\
\hline 06/09/2016 & 95 & 15.7 & 14.3 & 25.0 \\
\hline $12 / 09 / 2016$ & 111 & 37.7 & 54.5 & 40.0 \\
\hline $13 / 09 / 2016$ & 91 & 25.3 & 47.6 & 17.6 \\
\hline $19 / 09 / 2016$ & 67 & 14.0 & 28.6 & 13.3 \\
\hline 28/09/2016 & 50 & 20.3 & 44.0 & 42.9 \\
\hline $12 / 10 / 2016$ & NA & 39.3 & 66.1 & NA \\
\hline
\end{tabular}

NA: not available. 
$\left(\eta_{\mathrm{m}}\right)$ for ozone and particulate matter estimated according to Collett et al. (2008) as, $1-\left(\right.$ Conc $_{\mathrm{m}}$, intersticial $/$ Con $_{\mathrm{m}}$, pre-rain) where the prefix $m$ refers to $\mathrm{O}_{3}$ and particulate matter. Reported concentrations of $\mathrm{O}_{3}$ during the months of May and first half of June - corresponding to some of the highest pollution levels for 2016 - have a similar behavior to TC and NPOC results. Moreover, it is found that $\mathrm{O}_{3}$ is well correlated $\left(\mathrm{R}^{2}=0.69\right)$ with $\mathrm{PM}_{2.5}$ concentrations.

It can be observed that concentrations of the organic fraction in rainwater samples decrease as precipitation increases (Fig. 3). This behavior is similar to that reported by Pan et al. (2010) and Yan and Kim (2012), indicating that organics are washed out effectively during the initial stages of rain events. Precipitation is among the key factors controlling the pollution levels in the study area since it is considered to be the dominant scavenging mechanism in the atmosphere (Yan and Kim, 2012); therefore, it should represent an important cleansing mechanism. Associations between $\mathrm{O}_{3}$ and $\mathrm{PM}_{2.5}$ scavenging efficiencies with the amount of precipitation are shown in
Fig. 3b, c. Displayed results in these panels indicate higher efficiencies for $\mathrm{O}_{3}$ and $\mathrm{PM}_{2.5}$ scavenging as the amount of rain from an event increases, which is in agreement with the expected role of precipitation as an atmospheric cleansing process. However, there seems to be an apparent limit for the scavenging efficiency value, but the obtained data are insufficient to confirm this observation. The correlation between $\mathrm{PM}_{2.5}$ and rainfall, however, is not clear (Fig. 3c). This weak association may be due to a continuous supply of particulate matter during rain events (Kieber et al., 2002; Yan and Kim, 2012).

Figure 4 exhibits the association of NPOC observations with sulfur dioxide $\left(\mathrm{SO}_{2}\right)$ and carbon monoxide (CO). $\mathrm{SO}_{2}$ emissions from anthropogenic and natural sources are oxidized quickly in the atmosphere, leading to aerosol formation and acid deposition through sulfuric acid (Lee et al., 2011; He et al., 2012). Although $\mathrm{SO}_{2}$ emission have been reduced since 2006 due to changes in fuel formulations, the main sources of $\mathrm{SO}_{2}$ in the Mexico City area are industrial activities - especially power plants
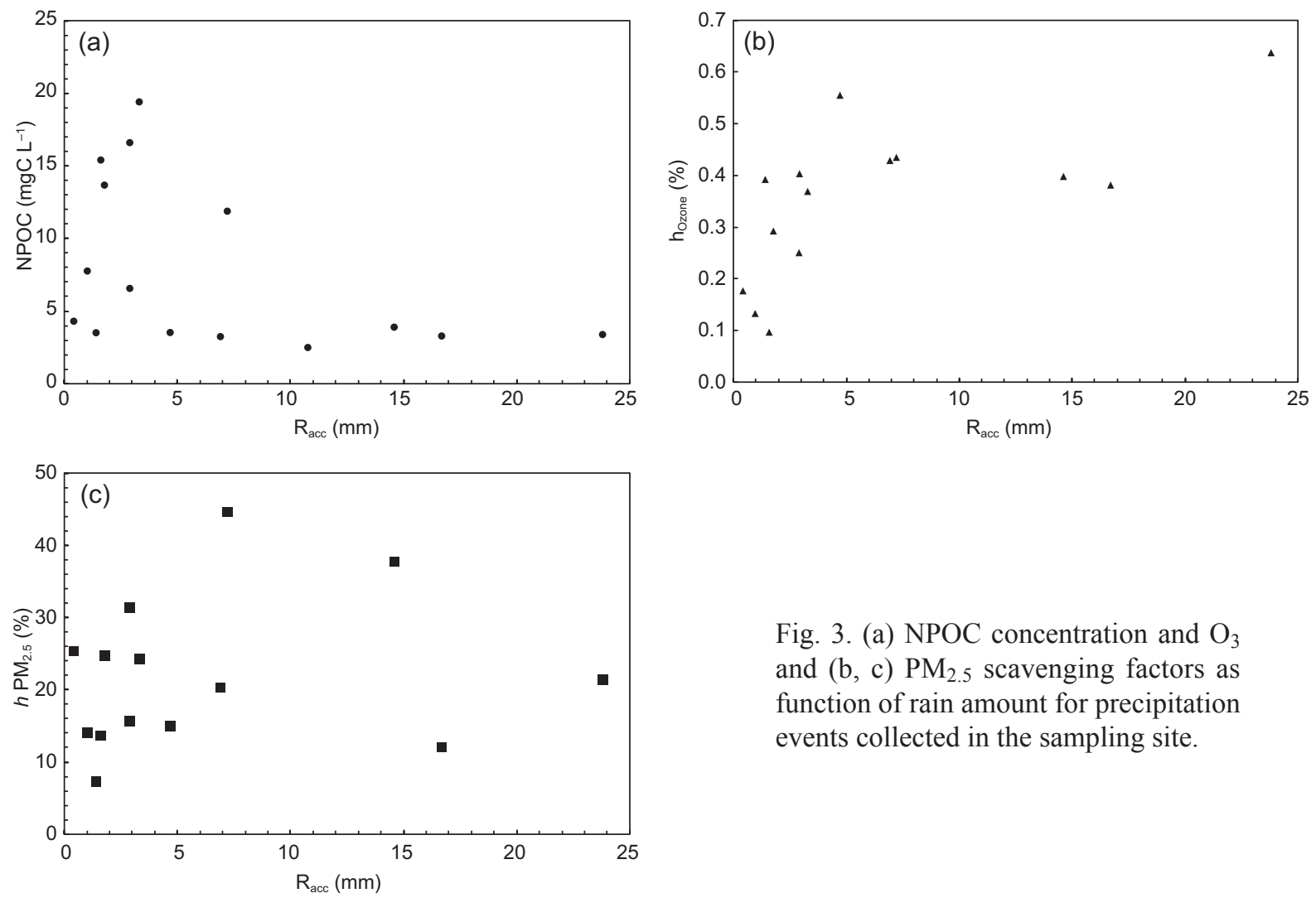

Fig. 3. (a) NPOC concentration and $\mathrm{O}_{3}$ and $(\mathrm{b}, \mathrm{c}) \mathrm{PM}_{2.5}$ scavenging factors as function of rain amount for precipitation events collected in the sampling site. 


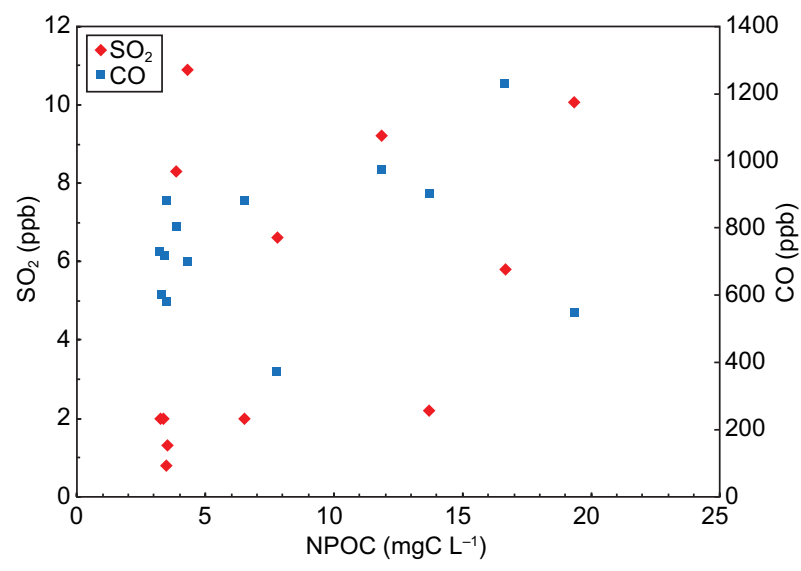

Fig. 4. Concentrations of sulfur dioxide (red diamonds) and carbon monoxide (blue squares) vs. NPOC for the studied rain events.

and the oil refinery in Tula, Hidalgo (northwest of the city). On the other hand, carbon monoxide (CO) is emitted from methane and non-methane hydrocarbon oxidation, from fossil fuel combustion (associated with car traffic, industry and domestic heating), and from vegetation burning for agricultural purposes or from wildfires (Clerbaux et al., 2008). CO in Mexico is mainly emitted from vehicles (Benítez at al., 2014). Data displayed in Figure 4 show a trend to larger NPOC concentrations as the amount of these pollutants increases. The association between NPOC and $\mathrm{CO}$ is more evident compared to the relation between NPOC and $\mathrm{SO}_{2}$, suggesting that the presence of water-soluble organic matter in the area is more dependent on local sources (vehicle emissions).

Meteorological and geographical conditions affect the evolution of pollutants (Sun et al., 2013; You et al., 2015) over the MCMA. The 48-h trajectories of air masses for 500 and $1500 \mathrm{~m}$ above the ground level for the studied rainstorms are shown in Figure 5. The trajectories evidence that air masses were located almost all the time over the continent, as suggested by the obtained results of organic and inorganic carbon contents in rainwater samples - which are higher than those representative for continental rain (Willey et al., 2000). With the aid of trajectory analyses, we tried to find a trend for the organic levels and $\mathrm{pH}$ values respect to the origin of air masses. The trajectory corresponding to $500 \mathrm{~m}$ above the ground was intended to look into the relation between the nearest (local) sources and the rainwater parameters studied in this work. The motivation for the corresponding trajectories at $1500 \mathrm{~m}$ above the ground was to study the influence of transport of pollutant sources located away from the sampling site. Panels (a) and (b) in Fig. 6 exhibit the NPOC results (concentric circles) for the rainstorms studied in this report in function of prevalent wind from the HYSPLIT diagrams. Although most of the storms were advected from the north-northeast, as expected according to Jáuregui (2000), data for the 500 and $1500 \mathrm{~m}$ levels do not show a clear relationship between the air masses' origin and those cases with high $\left(>10 \mathrm{mgC} \mathrm{L}^{-1}\right)$ carbon contents, since some of them arrived from north but others from other directions.

The $\mathrm{pH}$ varied from 4.2 to 7.3 and it is similar to the observations of Báez et al. (2007). Panels (c) and (d) in Fig. 6 display the $\mathrm{pH}$ values for the rainwater samples collected during the field campaign in function of wind direction for the selected height levels in the back-trajectory diagrams. Due to limited data, it is only possible to speculate about the location of pollutants sources near or within Mexico City that control the constituent levels in rainwater. A meticulous analysis of the $\mathrm{pH}$ and the mass air origin shows that most of the rainwater samples had $\mathrm{pH}$ greater than $5.6 \mathrm{pH}$ of rainwater in equilibrium with atmospheric $\mathrm{CO}_{2}$; Shukla and Sharma, 2010) when the wind pattern had a dominant northern or northeastern component. On the other hand, there is not any specific prevailing wind direction for those rainwater samples that had $\mathrm{pH}$ in the acidic range.

Physical and chemical interactions between aerosols and gases with cloud droplets and raindrops represent many uncertainties for the prediction of $\mathrm{pH}$ in rainwater. Even though there are important sources of $\mathrm{SO}_{2}$ in Tula, located north of the city, the $\mathrm{pH}$ of rainwater was not affected by these sources. Our results and other previous studies suggest that sources situated north of the sampling site have more influence on the rain neutralization processes reflected by decreasing pH. Báez et al. (2007) indicated that particles with $\mathrm{NH}_{4}{ }^{+}$and $\mathrm{Ca}^{2+}$ were among the main agents for rain neutralization in the basin of Mexico. $\mathrm{NH}_{4}{ }^{+}$is derived from cleaning items, industry, excrements and pet urine, and agricultural activities, whilst $\mathrm{Ca}^{2+}$ is sourced from soils located northeast of Mexico City. Furthermore, another plausible element for rain neutralization 


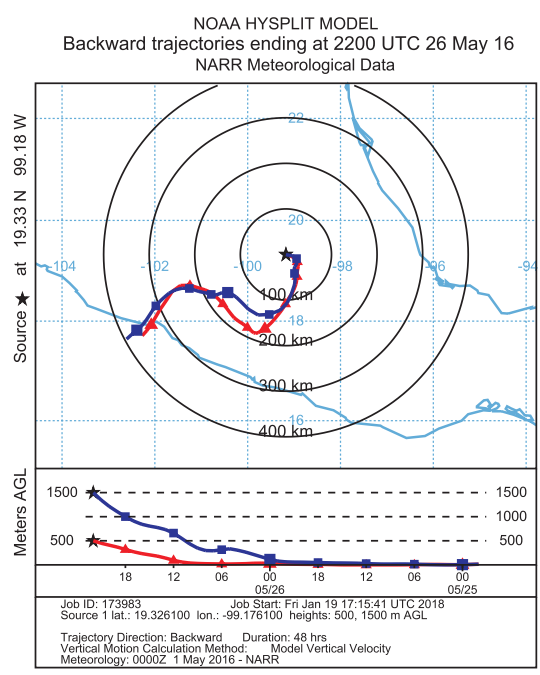

NOAA HYSPLIT MODEL
Backward trajectories ending at 0400 UTC 15 Jun 16
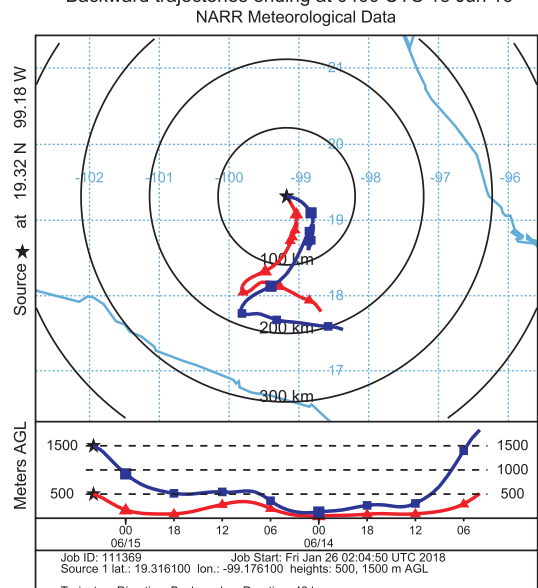

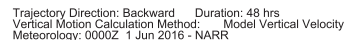

\section{NOAA HYSPLIT MODEL
Backward trajectories ending at 0100}

NARR Meteorological Data

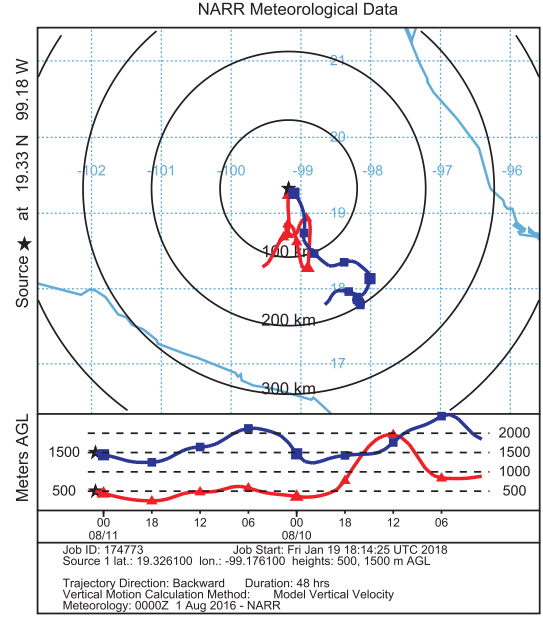

NOAA HYSPLIT MODEL

Backward trajectories ending at 1300 UTC 02 Jun 16 NARR Meteorological Data

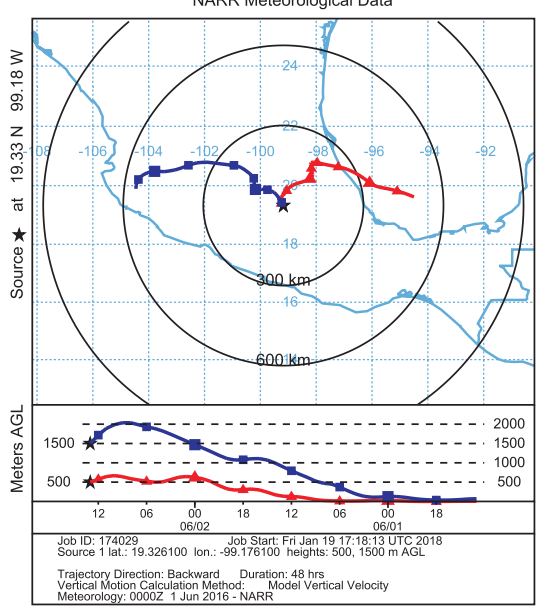

NOAA HYSPLIT MODEL

Backward trajectories ending at 2300 UTC 20 Jun 16 NARR Meteorological Data

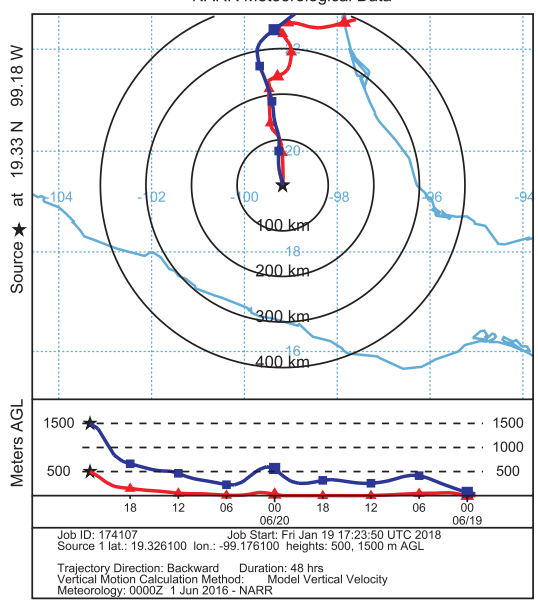

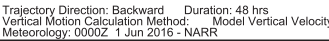

NOAA HYSPLIT MODEL

Backward trajectories ending at 2200 UTC 16 Aug 16 NARR Meteorological Data
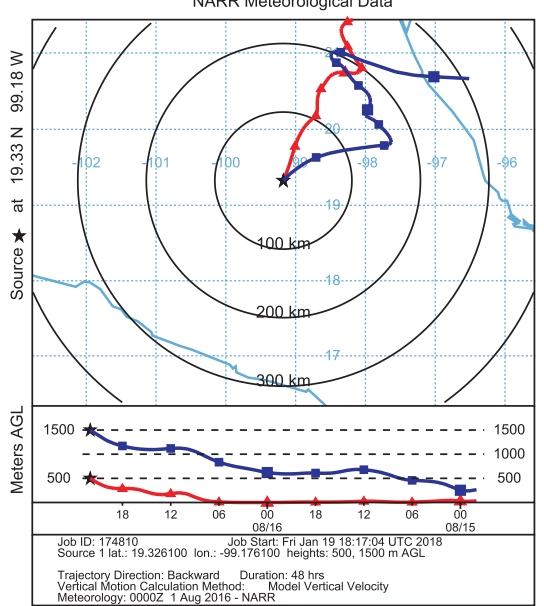

NOAA HYSPLIT MODEL

UTC 07 Jun 16 NARR Meteorological Data

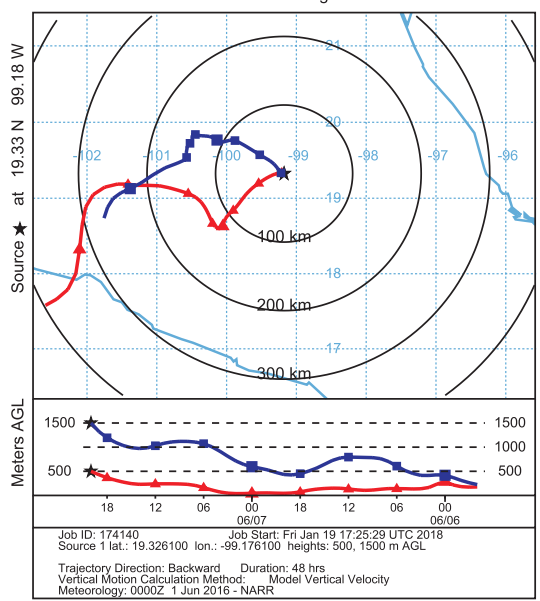

NOAA HYSPLIT MODEL

Backward trajectories ending at 2100 UTC 08 Aug 16

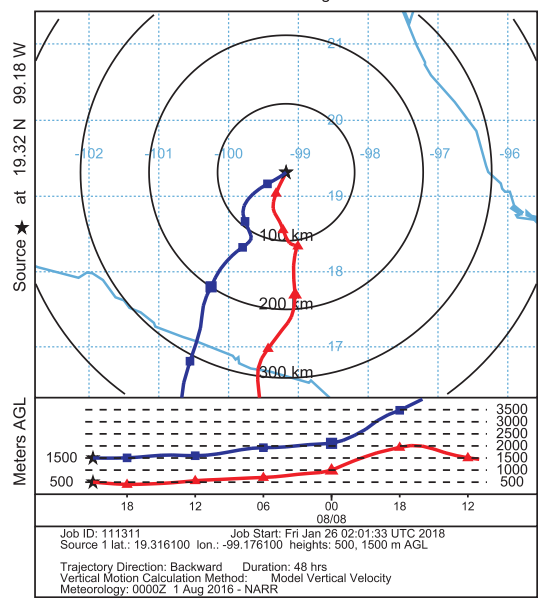

NOAA HYSPLIT MODEL

Backward trajectories ending at 2300 UTC 24 Aug 16 NARR Meteorological Data

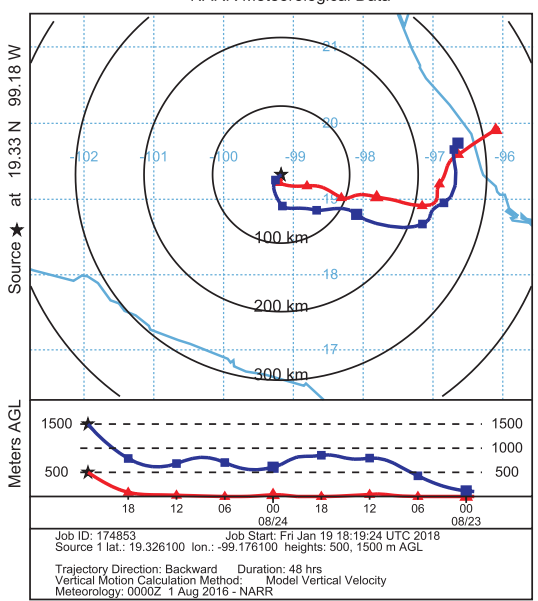

Fig. 5. (a) Air-mass back trajectories randomly selected for the field campaign observed during the rainy season of 2016. (b) Continuation of (a). 

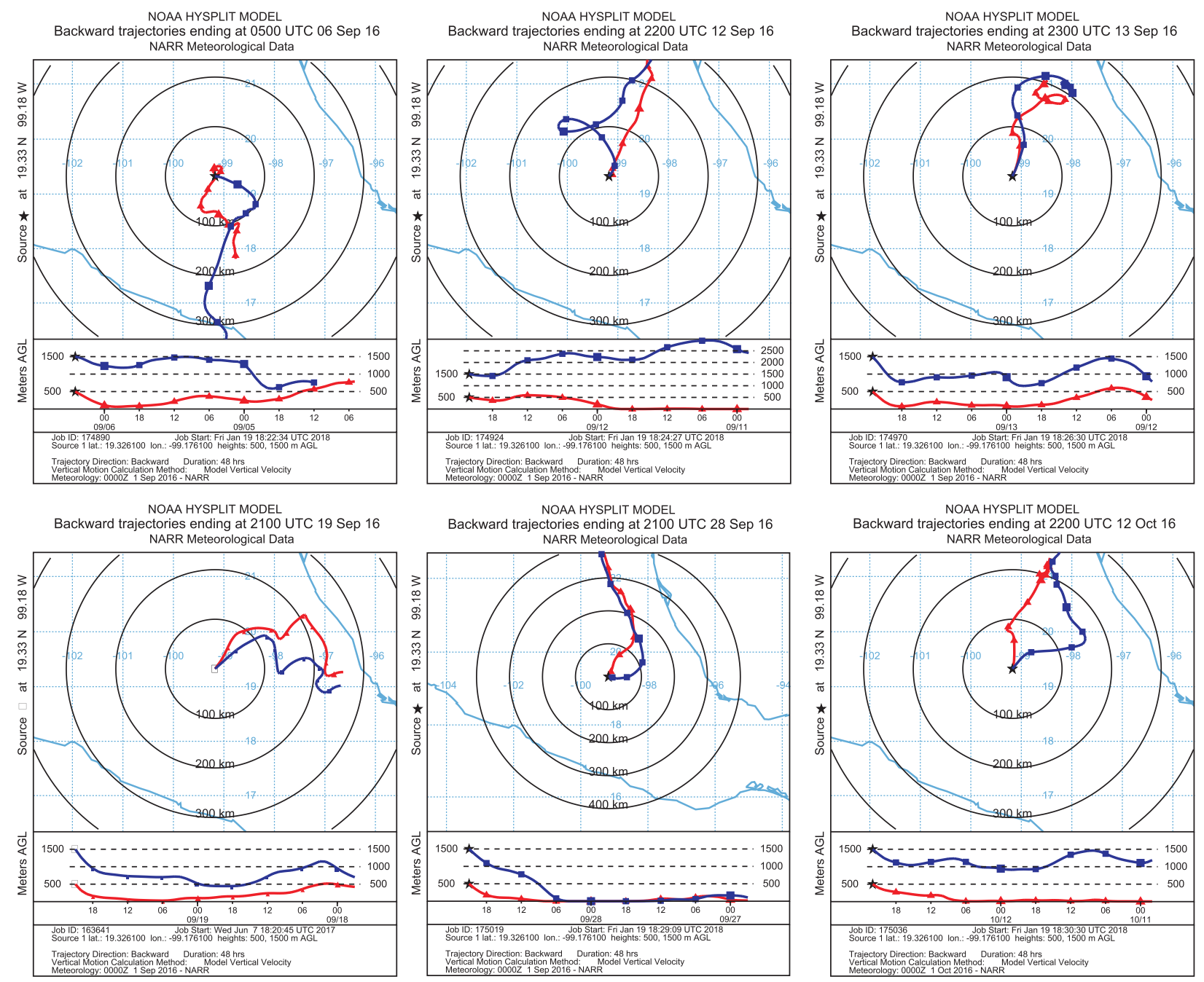

Fig. 5. (a) Air-mass back trajectories randomly selected for the field campaign observed during the rainy season of 2016. (b) Continuation of (a).

may be the scavenging of ammonia emitted by more than 4.8 million vehicles, most of them with catalytic converters (Perrino et al., 2002; INEGI, 2015).

\section{Summary and conclusions}

The present study reports water-soluble total and organic carbon contents in rainwater samples collected from the southwestern part of Mexico City during 2016 (May-October) and their chemical characteristics through a preliminary study. ${ }^{1} \mathrm{H}$ NMR analysis indicates the presence of aldehydes, carboxylic and other oxygenated groups present in aromatic and aliphatic hydrocarbons. Carbon analyses were performed using a Thermo Scientific HiperTOC analyzer to gather data of total as well as organic carbon, measured as NPOC. Results show notable changes in concentrations of both TC and OC during May-June (first part) and August-October (second part). Mean values for TC (22.2 $\left.\mathrm{mgC} \mathrm{L}^{-1}\right)$ and NPOC (15.7 $\left.\mathrm{mgC} \mathrm{L}^{-1}\right)$ in the first part were higher compared to the second part (TC, $12.3 \mathrm{mgC} \mathrm{L}^{-1}$; NPOC, $4.2 \mathrm{mgC} \mathrm{L}^{-1}$ ). The chemical characteristics and concentration values are comparable to organic content observed in other urban areas throughout the world. Furthermore, the NPOC/TC ratio for rainwater samples decreased during the second part of the campaign (the amount of organics render the $71 \%$ of the total carbon detected 


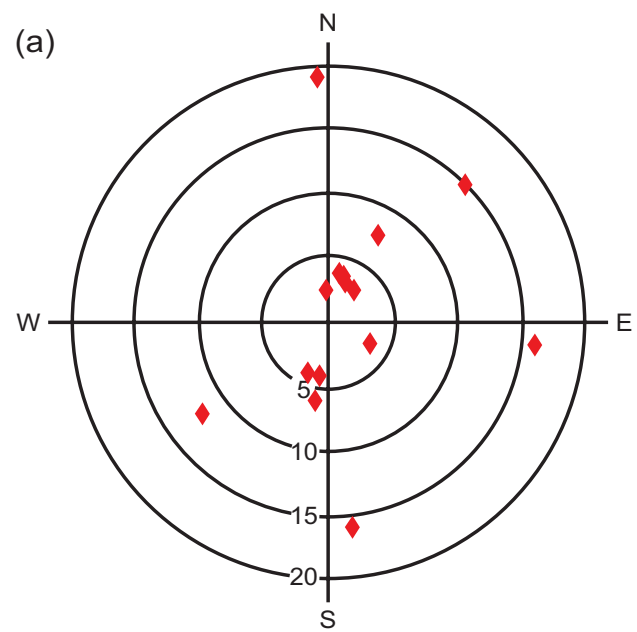

NPOC $\left(\mathrm{mgC} \mathrm{L}^{-1}\right)$

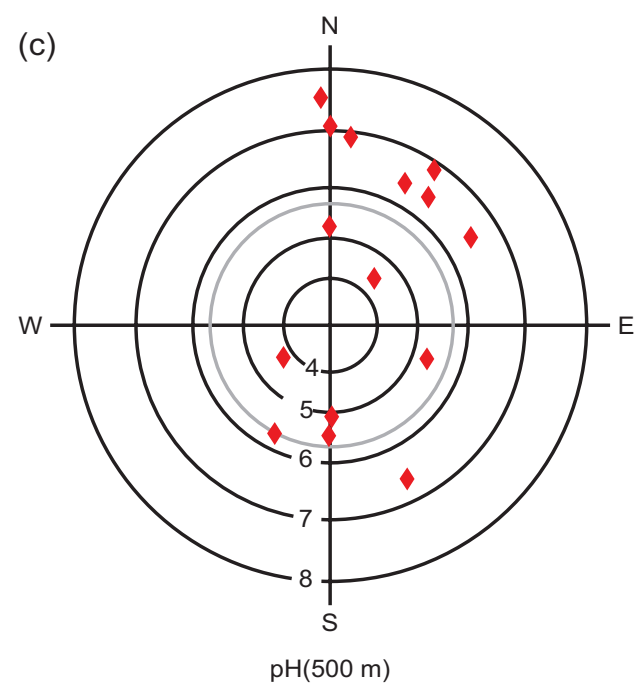

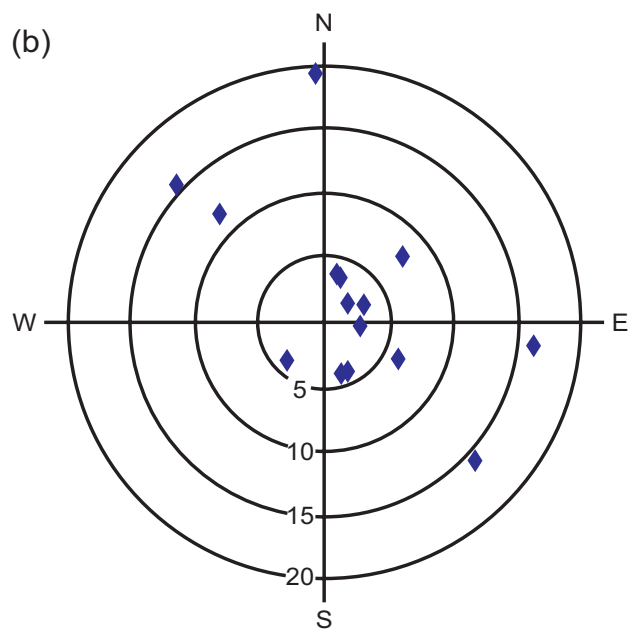

$\operatorname{NPOC}\left(\mathrm{mgC} \mathrm{L}^{-1}\right)$

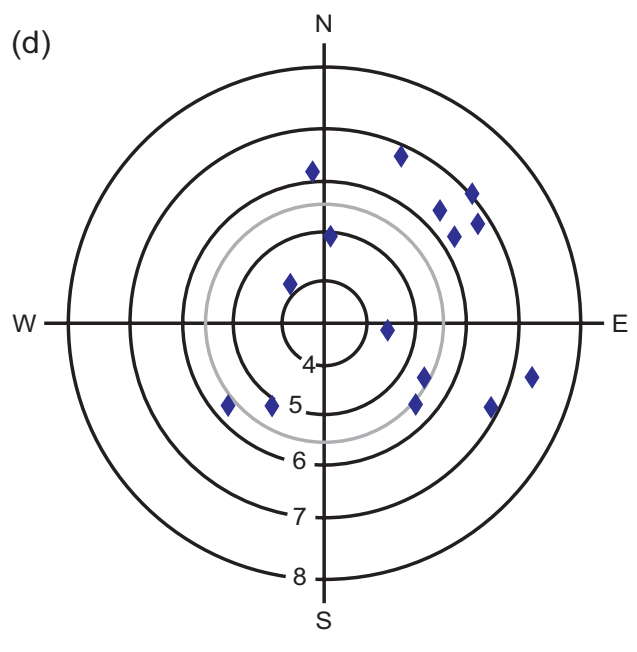

$\mathrm{pH}(1500 \mathrm{~m})$

Fig. 6. Measurements of NPOC concentrations and $\mathrm{pH}$ (in concentric circles) for the rainwater samples collected during the field campaign in function of wind direction for the 500 (red diamonds) and $1500 \mathrm{~m}$ (blue diamonds) above the ground. Vertical and horizontal lines refer to the cardinal coordinates. The wind direction corresponds to the component $6 \mathrm{~h}$ before rain occurrence. The grey circles in $\mathrm{pH}$ panels indicate the limit for neutral $\mathrm{pH}$ of atmospheric water with $\mathrm{CO}_{2}$ equilibrium. Points outside this circle identify rainwater samples from alkaline events.

during the first part of the campaign but it decreased to $34 \%$ during the last one). However, the inorganic carbon concentration was $7.6 \mathrm{mgC} \mathrm{L}^{-1}$ in average and it is higher than the continental rain, suggesting that local sources contribute to this carbonaceous fraction. Analysis of air trajectories for 500 and 1500 $\mathrm{m}$ above the ground level did not show an association between carbon contents in rainwater and the air mass origin. It suggests that most of the carbon detected in rain samples was produced by local sources. We observed that rainwater $\mathrm{pH}$ tends to be alkaline when the wind direction had a dominant north or northeast component. Similar to the observations of Báez et al. (2007), the industrial emissions and particles from sediments and soils from the northern parts of the city could be the neutralizing agents. Moreover, the scavenging of ammonia emitted by vehicles was another plausible element for rain neutralization. The organic 
compounds (aromatic and alkenes) control production of daytime ozone in the MCMA (e.g., Tie et al., 2007) and we observed some of the highest NPOC levels and higher concentrations of $\mathrm{O}_{3}$ during May and the first half of June. More data, however, is required to relate the organic concentrations in rainwater with the pollution levels in the basin.

\section{Acknowledgments}

This research was funded by the UNAM-DGAPA-PAPIIT (IA100715) program. The authors acknowledge Ana Rosa Flores Márquez, Rocío García Martínez, José Manuel Hernández, and Alfredo Rodríguez Manjarrez for support during the field campaign, and Bertha Eugenia Mar Morales and Víctor Zarraluqui for the elaboration of the figures. The authors are also grateful to an anonymous reviewer for his valuable comments.

\section{References}

Báez A., Belmont R., González O.G. and Rosas I.P., 1989. Formaldehyde levels in air and wet precipitation at Mexico City, Mexico. Environ. Pollut. 62, 153-169. DOI: 10.1016/0269-7491(89)90184-X

Báez A., Padilla H. and Belmont R., 1993. Scavenging of atmospheric formaldehyde by wet precipitation. Environ. Pollut. 79, 271-275.

DOI: 10.1016/0269-7491(93)90100-3

Báez A., Belmont R., García R., Torres M.C. and Padilla H.G., 2006. Rainwater chemical composition at two sites in Central Mexico. Atmos. Res. 80, 67-85.

DOI: 10.1016/j.atmosres.2005.06.008

Báez A., Belmont R., García R., Padilla H. and Torres M.C., 2007. Chemical composition of rainwater collected at a southwest site of Mexico City, Mexico. Atmos. Res. 86, 61-75. DOI: 10.1016/j.atmosres.2007.03.005

Báez A., Torres M.C., García R., Padilla H. and Belmont R., 2008. Measurement of carbonyls in three urban zones of the Mexico City metropolitan area and one rural zone. Open Atmos. Sci. J. 2, 61-67. DOI: 10.2174/1874282300802010061

Báez A., Belmont R., García R., Padilla H.G. and Torres M.C., 2009. Trends in chemical composition of wet precipitation in Mexico City, Mexico: 1992-2007. Open Atmos. Sci. J. 3, 187-195.

DOI: $10.2174 / 1874282300903010187$
Balla D., Papageorgiou A. and Voutsa D., 2014. Carbonyl compounds and dissolved organic carbon in rainwater of an urban atmosphere. Environ. Sci. Pollut. Res. 21, 12062-12073. DOI: 10.1007/s11356-014-3080-8

Benítez-García S.E., Kanda I., Wakamatsu S., Okazaki Y. and Kawano M., 2014. Analysis of criteria air pollutant trends in three Mexican metropolitan areas. Atmosphere 5, 806-829. DOI: 10.3390/atmos5040806

Bisutti I., Hilke I. and Raessler M., 2004. Determination of total organic carbon-An overview of current methods. Trends Anal. Chem. 23, 716-726.

DOI: $10.1016 /$ j.trac.2004.09.003

Campos M.L.A.M., Nogueira R.F.P., Dametto P.R., Francisco J.G. and Coelho C.H., 2007. Dissolved organic carbon in rainwater: Glassware decontamination and sample preservation and volatile organic carbon. Atmos. Environ. 41, 8924-8931.

DOI: 10.1016/j.atmosenv.2007.08.017

Cavalli F., Facchini M.C., Decesari S., Emblico L., Mircea M., Jensen N.R. and Fuzzi S., 2006. Size-segregated aerosol chemical composition at a boreal site in southern Finland, during the QUEST project. Atmos. Chem. Phys. 6, 993-1002. DOI: 10.5194/acp-6-993-2006

Chon K., Kim Y., Bae D.H. and Cho J., 2015. Confirming anthropogenic influences on the major organic and inorganic constituents of rainwater in an urban area. Drink. Water Eng. Sci. 8, 35-48.

DOI: $10.5194 /$ dwes-8-35-2015

Clerbaux C., Edwards D.P., Deeter M., Emmons L., Lamarque J.-F., Tie X.X., Massie S.T. and Gille J., 2008. Carbon monoxide pollution from cities and urban areas observed by the Terra/MOPITT mission. Geophys. Res. Lett. 35, L03817.

DOI: 10.1029/2007GL032300

Coelho C.H., Francisco J.G., Nogueira R.F.P. and Campos M.L.A.M., 2008. Dissolved organic carbon in rainwater from areas heavily impacted by sugar cane burning. Atmos. Environ. 42, 7115-7121.

DOI: 10.1016/j.atmosenv.2008.05.072.

Collett Jr. J.L., Herckes P., Youngster S. and Lee T., 2008. Processing of atmospheric organic matter by California radiation fogs. Atmos. Res. 87, 232 - 241.

DOI: 10.1016/j.atmosres.2007.11.005

Ćosović B., Orlović-Leko P. and Kozarac Z., 2007. Rainwater dissolved organic carbon: characterization of surface active substances by electrochemical method. Electroanalysis 19, 2077-2084.

DOI: 10.1002/elan.200703907 
Decesari S., Facchini M.C., Fuzzi S. and Tagliavini E., 2000. Characterization of water-soluble organic compounds in atmospheric aerosol: A new approach. J. Geophys. Res. 105, 1481-1489.

DOI: 10.1029/1999JD900950

Duarte R.M. and Duarte A.C., 2011. A critical review of advanced analytical techniques for water-soluble organic matter from atmospheric aerosols. Trends Anal. Chem. 30, 1659-1671. DOI: 10.1016/j.trac.2011.04.020

Facchini M.C., Mircea M., Fuzzi S. and Charlson R.J., 1999. Cloud albedo enhancement by surface-active organic solutes in growing droplets. Nature 401, 257 259. DOI: $10.1038 / 45758$

García R., Torres M.C., Padilla H., Belmont R., Azpra E., Arcega-Cabrera F. and Báez A., 2006. Measurement of chemical elements in rain from Rancho Viejo, a rural wooded area in the State of Mexico, Mexico. Atmos. Environ. 40, 6088-6100.

DOI: $10.1016 /$ j.atmosenv.2006.05.048

Gilardoni S., Liu S., Takahama S., Russell L.M., Allan J.D., Steinbrecher R., Jimenez J.L., de Carlo P.F., Dunlea E.J. and Baumgardner D., 2006. Characterization of organic ambient aerosol during MIRAGE 2006 on three platforms. Atmos. Chem. Phys. 9, 5417-5432. DOI: 10.5194/acp-9-5417-2009

Gilardoni S., Massoli P., Paglione M., Giulianelli L., Carbone C., Rinaldi M., Decesari S., Sandrini S., Costabile F., Gobbi G.P., Pietrogrande M.C., Visentin M., Scotto F., Fuzzi S. and Facchini M.C., 2016. Direct observation of aqueous secondary organic aerosol from biomass-burning emissions. P. Natl. Acad. Sci. USA 113, 10013-10018.

DOI: $10.1073 /$ pnas. 1602212113

Graber E.R. and Rudich Y., 2006. Atmospheric HULIS: How humic-like are they? A comprehensive and critical review. Atmos. Chem. Phys. 6, 729-753.

DOI: 10.5194/acp-6-729-2006

Graham B., Mayol-Bracero O.L., Guyon P., Roberts G.C., Decesari S., Facchini M.C., Artaxo P., Maenhaunt W., Köll P. and Andreae M.O., 2002. Water-soluble organic compounds in biomass burning aerosols over Amazonia 1. Characterization by NMR and GC-MS. J. Geophys. Res. 107, 8047. DOI: 10.1029/2001JD000336

Guidotti M., Giovinazzo R., Cedrone O. and Vitali M., 2000. Determination of organic micropollutants in rain water for laboratory screening of air quality in urban environment. Environ. Int. 26, 23-28.

DOI: $10.1016 / \mathrm{S} 0160-4120(00) 00074-\mathrm{X}$
He H., Li C., Loughner C.P., Li Z., Krotkov N.A., Yang K., Wang L., Zheng Y., Bao X., Zhao G. and Dickerson R.R., 2012. $\mathrm{SO}_{2}$ over central China: Measurements, numerical simulations and the tropospheric sulfur budget. J. Geophys. Res. 117, D00K37.

DOI: 10.1029/2011JD016473

Huang X.-F., Yu J.Z., He L.-Y. and Yuan Z., 2006. Water-soluble organic carbon and oxalate in aerosols at a coastal urban site in China: Size distribution characteristics sources and formation mechanisms. J. Geophys. Res. Atmos. 111, D22212.

DOI: $10.1029 / 2006 J D 007408$

Iavorivska L., Boyer E.W. and DeWalle D.R, 2016. Atmospheric deposition of organic carbon in precipitation. Atmos. Environ. 146, 153-163.

DOI: $10.1016 /$ j.atmosenv.2016.06.006

INEGI, 2015. Instituto Nacional de Estadística y Geografía. Available at: http://www.beta.inegi.org.mx/app/ buscador/default.html?q=veh\%C3\%ADculos\#tabM Ccollapse-Indicadores (last accessed on July 2017)

Jáuregui E., 2000. El clima de la ciudad de México. Instituto de Geografía, UNAM/Plaza y Valdés, México, 131 pp.

Kanakidou M., Seinfeld J., Pandis S., Barnes I., Dentener F., Facchini M.C., van Dingenen R., Ervens B., Nenes A., Nielsen C.J., Swietlicki E., Putaud J.P., Balkanski Y., Fuzzi S., Horth J., Moortgat G., Winterhalter R., Myhre C., Tsigaridis K., Vignati E., Stephanou E. and Wilson J., 2005. Organic aerosol and climate modeling: a review. Atmos. Chem. Phys. 5, 1053-1123.

DOI: $10.5194 / \mathrm{ACP}-5-1053-2005$

Kawamura K., Steinberg S., Ng L. and Kaplan I.R., 2001. Wet deposition of low molecular weight mono- and di-carboxylic acids, aldehydes and inorganic species in Los Angeles. Atmos. Environ. 35, 3917-3926.

DOI: $10.1016 / \mathrm{S} 1352-2310(01) 00207-2$

Kieber R.B., Peake B., Willey J.D. and Avery G.B., 2002. Dissolved organic carbon and organic acids in coastal New Zealand rainwater. Atmos. Environ. 36, 35573563. DOI: 10.1016/S1352-2310(02)00273-X

Kondo Y., Miyazaki Y., Takegawa N., Miyakawa T., Weber R.J., Jiménez J.L., Zhang Q. and Worsnop D.R., 2007. Oxygenated and water-soluble organic aerosols in Tokyo. J. Geophys. Res. 112, D01203.

DOI: 10.1029/2006JD007056

Kucieńska B., Montero-Martínez G. and García-García F., 2010. A simulation of the influence of organic and inorganic pollutants on the formation and development of warm clouds over Mexico City. Atmos. Res. 95, 
487-495. DOI: 10.1016/j.atmosres.2009.11.011

Lee C., Martin R.V., van Donkelaar A., Lee H., Dickerson R.R., Hains J.C., Krotkov N., Richter A., Vinnikov K. and Schwab J.J., 2011. $\mathrm{SO}_{2}$ emissions and lifetimes: Estimates from inverse modeling using in situ and global, space-based (SCIAMACHY and OMI) observations. J. Geophys. Res. 116, D06304.

DOI: 10.1029/2010JD014758

Liu C.J., Hannu I., Werner K., Ma X.Q., Carl J.W. and Pekka K., 2004. An estimate on the rainout of atmospheric $\mathrm{CO}_{2}$. J. Environ. Sci. 1, 86-89

Moffet R.C., Henn T.R., Tivanski A.V., Hopkins R.J., Desyaterik Y., Kilcoyne A.L.D., Tyliszczak T., Fast J., Barnard J., Shutthanandan V., Cliff S.S., Perry K.D., Laskin A. and Gilles M.K., 2010. Microscopic characterization of carbonaceous aerosol particle aging in the outflow from Mexico City. Atmos. Chem. Phys. 10, 961-976.

DOI: $10.5194 /$ acp-10-961-2010

Montero-Martínez G., Zarraluqui-Such V., Caetano E.S. and García-García F., 2011. Hydrometeor vertical characterization of precipitating clouds over the Mexico Basin. Int. J. Remote Sens. 32, 6367-6378.

DOI: $10.1080 / 01431161.2010 .510489$

Nozière B., Kalberer M., Claeys M., Allan J., D’Anna B., Decesari S., Finessi E., Glasius M., Grgic I., Hamilton J.F., Hoffmann T., Iinuma Y., Jaoui M., Kahnt A., Kampf C.J., Kourtchev I., Maenhaut W., Marsden N., Saarikoski S., Schnelle-Kreis J., Surratt J.D., Szidat S., Szmigielski R. and Wisthaler A., 2015. The molecular identification of organic compounds in the atmosphere: State of the art and challenges. Chem. Rev. 115, 39193983. DOI: $10.1021 / \mathrm{cr} 5003485$

Orlović-Leko P., Kozarac Z., Ćosović B., Strmečki S. and Plavšić M., 2010. Characterization of atmospheric surfactants in the bulk precipitation by electrochemical tools. J. Atmos. Chem. 66, 11-26.

DOI 10.1007/s10874-011-9189-y

Pan Y., Wang Y., Xin J., Tang G., Song T., Wang Y., Li X. and Wu F., 2010. Study on dissolved organic carbon in precipitation in Northern China. Atmos. Environ. 44, 2350-2357.

DOI: $10.1016 /$ j.atmosenv.2010.03.033

Perrino C., Catrambone M., di Bucchianico A.D.M. and Allegrini I., 2002. Gaseous ammonia in the urban area of Rome, Italy and its relationship with traffic emissions. Atmos. Environ. 36, 5385-5394.

DOI: 10.1016/S1352-2310(02)00469-7
Pretsch E., Bhuhlmann P. and Badertscher M., 2009. ${ }^{1} \mathrm{H}$ NMR Spectroscopy. In: Structure determination of organic compounds. Tables of spectral data (Badertscher M., Bühlmann P. and Pretsch E., Eds.). Springer-Verlag, Berlin, pp. 157-238.

DOI: 10.1007/978-3-540-93810-1_4

Putaud J., Raes F., van Dingenen R., Brüggemann E., Facchini M.C., Decesari S., Fuzzi S., Gehrig R., Hüglin C., Laj P., Lorbeer G., Maenhaut W., Mihalopoulos N., Müller K., Querol X., Rodriguez S., Schneider J., Spindler G., ten Brink H., Tørseth K. and Wiedensohler A., 2004. A European aerosol phenomenology -2 : Chemical characteristics of particulate matter at kerbside, urban, rural and background sites in Europe. Atmos. Environ. 38, 2579-2595.

DOI: $10.1016 /$ j.atmosenv.2004.01.041

Saarikoski S., Timonen H., Saarnio K., Aurela M., Järvi L., Keronen P., Kerminen V.-M. and Hillamo R., 2008. Sources of organic carbon in fine particulate matter in northern European urban air. Atmos. Chem. Phys. 8, 6281-6295.

DOI: $10.5194 / \mathrm{acp}-8-6281-2008$

Salcedo D., Onasch T.B., Dzepina K. Canagaratna, M.R., Zhang Q., Huffman J.A., DeCarlo P.F., Jayne J.T., Mortimer P., Worsnop D.R., Kolb C.E., Johnson K.S., Zuberi B., Marr L.C., Volkamer R., Molina L.T., Molina M.J., Cárdenas B., Bernabé R.M., Márquez C., Gaffney J.S., Marley N.A., Laskin A., Shutthanandan V., Xie Y., Brune W., Lesher R., Shirley T. and Jiménez J.L., 2006. Characterization of ambient aerosols in Mexico City during the MCMA-2003 campaign with aerosol mass spectrometry: Results from the CENICA supersite. Atmos. Chem. Phys. 6, 925-946.

DOI: 10.5194/acp-6-925-2006

Santos P.S., Otero M., Duarte R.M. and Duarte A.C., 2009. Spectroscopic characterization of dissolved organic matter isolated from rainwater. Chemosphere 74, 1053-1061.

DOI: $10.1016 /$ j.chemosphere.2008.10.061

Saxena P. and Hildemann L.M., 1996. Water-soluble organics in atmospheric particles: A critical review of the literature and application of thermodynamics to identify candidate compounds. J. Atmos. Chem. 24, 57-109.

DOI: $10.1007 / \mathrm{BF} 00053823$

Seinfeld J.H. and Pandis S.N., 2006. Atmospheric Chemistry and Physics. From air pollution to climate change. John Wiley and Sons, New Jersey, pp. 761-923. 
Sempere R. and Kawamura K., 1994. Comparative distributions of dicarboxylic acids and related polar compounds in snow, rain and aerosols from urban atmosphere. Atmos. Environ. 28, 449-459.

DOI: 10.1016/1352-2310(94)90123-6

Shukla S.P. and Sharma M., 2010. Neutralization of rainwater acidity at Kanpur, India. Tellus B 62, 172-180. DOI: $10.1111 / \mathrm{j} .1600-0889.2010 .00454 . \mathrm{x}$

Siudek P., Frankowski M. and Siepak J., 2015. Seasonal variations of dissolved organic carbon in precipitation over urban and forest sites in central Poland. Environ. Sci. Pollut. Res. 22, 11087-11096.

DOI: $10.1007 / \mathrm{s} 11356-015-4356-3$

Stein A.F., Draxler R.R., Rolph G.D., Stunder J.B., Cohen M.D. and Ngan F., 2015. NOAA's HYSPLIT atmospheric transport and dispersion modeling system. Bull. Amer. Meteor. Soc. 96, 2059-2077.

DOI: 10.1175/BAMS-D-14-00110.1

Sullivan A.P., Peltier R.E., Brock C.A., de Gouw J.A., Holloway J.S., Warneke C., Wollny A.G. and Weber R.J., 2006. Airborne measurements of carbonaceous aerosol soluble in water over northeastern United States: Method development and an investigation into water-soluble organic carbon sources. J. Geophys. Res. 111, D23S46. DOI: 10.1029/2006JD007072

Sun J. and Ariya P.A., 2006. Atmospheric organic and bio-aerosols as cloud condensation nuclei $(\mathrm{CCN})$ : A review. Atmos. Environ. 40, 795-820.

DOI: 10.1016/j.atmosenv.2005.05.052

Sun Y.L., Wang Z.F., Fu P.Q., Yang T., Jiang Q., Dong H.B., Li J., and Jia J.J., 2013. Aerosol composition, sources and processes during wintertime in Beijing, China. Atmos. Chem. Phys. 13, 4577-4592.

DOI: $10.5194 /$ acp-13-4577-2013

Suzuki Y., Kawakami M. and Akasaka K., 2001. ${ }^{1} \mathrm{H}$ NMR application for characterizing water-soluble organic compounds in urban atmospheric particles. Environ. Sci. Technol. 35, 3272-3272. DOI: 10.1021/es001861a Thermo Scientific, 2007. HiperTOC User's Manual. Version 2.0.3. Delft, Netherlands.

Tie X., Madronich S., Li G.H., Ying Z.M., Zhang R. García, A., Lee-Taylor J. and Liu Y., 2007. Characterizations of chemical oxidants in Mexico City: A regional chemical/dynamical model (WRF-Chem) study. Atmos. Environ. 41, 1989-2008.
DOI: 10.1016/j.atmosenv.2006.10.053

Tsimpidi A.P., Karydis V.A., Zavala M., Lei W., Bei N., Molina L. and Pandis S.N., 2011. Sources and production of organic aerosol in Mexico City: Insights from the combination of a chemical transport model (PMCAMx-2008) and measurements during MILAGRO. Atmos. Chem. Phys. 11, 5153-5168.

DOI: $10.5194 /$ acp-11-5153-2011

Willey J.D., Kieber R.J., Eyman M.S. and Avery G.B., 2000. Rainwater dissolved organic carbon: Concentrations and global flux. Glob. Biogeochem. Cycles. 14, 139-148. DOI: 10.1029/1999GB900036

Xu T., Song Z., Liu J., Wang C., Wei J. and Chen H., 2008. Organic composition in the dry season rainwater of Guangzhou, China. Environ. Geochem. Health 30, 53-65. DOI: $10.1007 / \mathrm{s} 10653-007-9107-\mathrm{z}$

Yan G. and Kim G., 2012. Dissolved organic carbon in the precipitation of Seoul, Korea: Implications for global wet depositional flux of fossil-fuel derived organic carbon. Atmos. Environ. 59, 117-124.

DOI: 10.1016/j.atmosenv.2012.05.044

You C., Gao S. and Xu C., 2015. Biomass burning emissions contaminate winter snowfalls in urban Beijing: A case study in 2012. Atmos. Poll. Res. 6, 376-381. DOI: 10.5094/APR.2015.041.

Zhang Q., Jiménez J.L., Canagaratna M.R, Allan J.D., Coe H., Ulbrich I., Alfarra M.R., Takami A., Middlebrook A.M., Sun Y.L., Dzepina K., Dunlea E., Docherty K., DeCarlo P.F., Salcedo D., Onasch T., Jayne J.T., Miyoshi T., Shimono A., Hatakeyama S., Takegawa N., Kondo Y., Schneider J., Drewnick F., Borrmann S., Weimer S., Demerjian K., Williams P., Bower K., Bahreini R., Cottrell L., Griffin R.J., Rautiainen J., Sun J.Y., Zhang Y.M. and Worsnop D.R., 2007. Ubiquity and dominance of oxygenated species in organic aerosols in anthropogenically-influenced Northern Hemisphere midlatitudes. Geophys. Res. Lett. 34, L13801.

DOI: 10.1029/2007GL029979 